\title{
The impact of improving feed efficiency on the environmental impact of livestock production
}

Book or Report Section

Published Version

Drackley, J. K. and Reynolds, C. K. ORCID:

https://orcid.org/0000-0002-4152-1190 (2021) The impact of improving feed efficiency on the environmental impact of livestock production. In: Baines, R. (ed.) Reducing greenhouse gas emissions from livestock production. Burleigh Dodds Series in Agricultural Science. Burleigh Dodds Science Publishing. ISBN 9781786764393 doi:

https://doi.org/10.19103/AS.2020.0077.10 Available at https://centaur.reading.ac.uk/101160/

It is advisable to refer to the publisher's version if you intend to cite from the work. See Guidance on citing.

Identification Number/DOI: https://doi.org/10.19103/AS.2020.0077.10

<https://doi.org/10.19103/AS.2020.0077.10>

Publisher: Burleigh Dodds Science Publishing

Publisher statement: Recent IPCC reports have highlighted the environmental impact of livestock production as a major source of non-CO2 emissions: methane $(\mathrm{CH} 4)$, nitrous oxide (N2O) and ammonia $(\mathrm{NH} 3)$. The livestock sector must react to these reports and develop or implement methods that can reduce greenhouse (GHG) emissions from livestock production. Reducing greenhouse gas emissions from livestock production provides authoritative reviews on measuring GHG 


\section{University of \\ $\$$ Reading}

emissions from livestock as well as the range of methods that can be applied to reduce emissions, ranging from breeding to animal health and manure management. The collection also reviews nutritional approaches such as improving forage quality and the use of plant bioactive compounds and other feed supplements to limit emissions by modifying the rumen environment. Drawing in an international range of expert authors, Reducing greenhouse gas emissions from livestock production summarises what we can do to make livestock production more sustainable and viable for the future. It will be a major reference for the livestock (particularly dairy) science research community, environmental scientists, government and other agencies tackling the challenge of climate change, as well as companies involved in livestock production and processing of dairy and meat products. Key features A comprehensive review of both the causes of greenhouse gas emissions from livestock and the range of ways these emissions can be reduced Particularly strong focus on the range of nutritional strategies, from forage and silage to feed supplements such as plant bioactive compounds and direct-fed microbials as well as inhibitors and vaccines Covers other approaches such as genetics and selection, improved husbandry as well as manure management

All outputs in CentAUR are protected by Intellectual Property Rights law, including copyright law. Copyright and IPR is retained by the creators or other copyright holders. Terms and conditions for use of this material are defined in the End User Agreement.

\section{$\underline{\text { www.reading.ac.uk/centaur }}$}

\section{CentAUR}

Central Archive at the University of Reading

Reading's research outputs online 


\section{Reducing greenhouse}

gas emissions from

livestock production

Edited by Dr Richard Baines, Royal Agricultural University, UK

\section{ECFIAPUER FROM UHIS 300K}

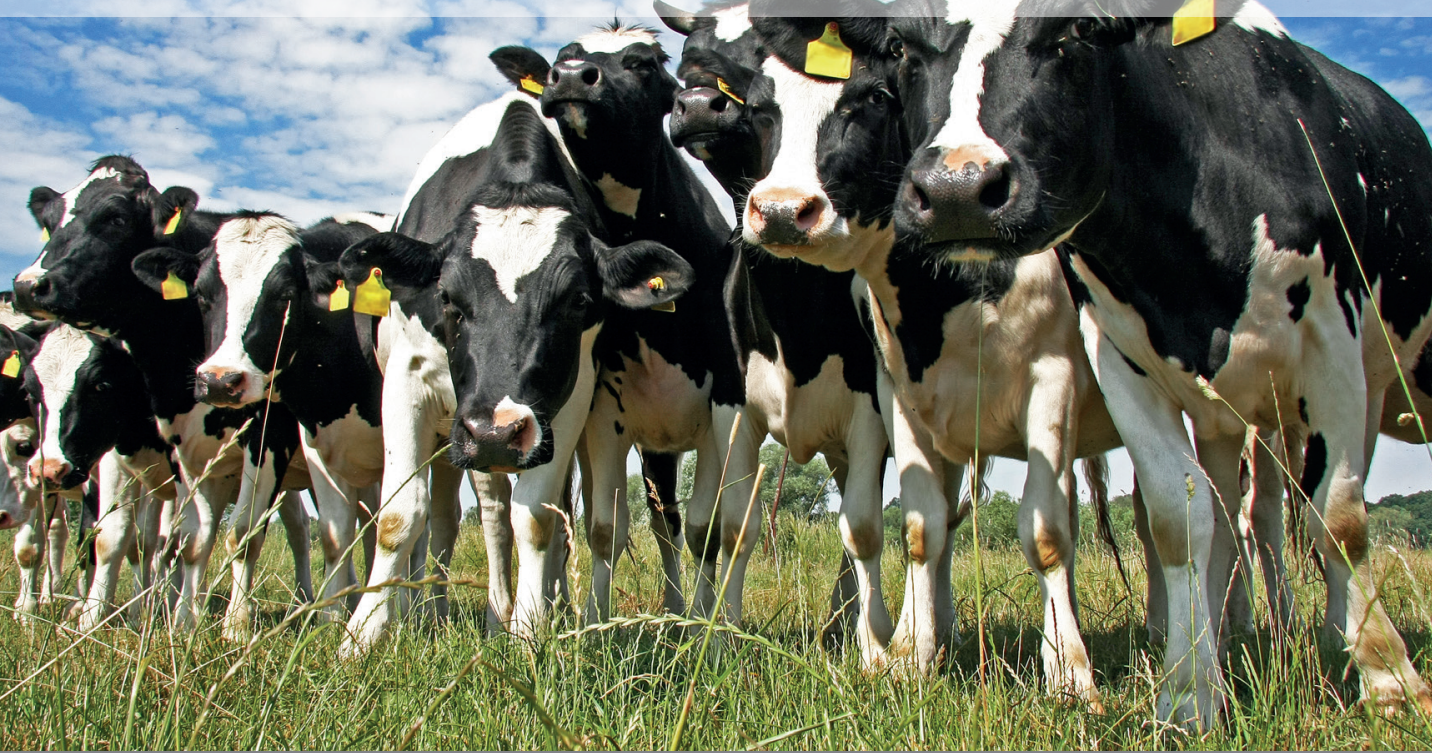

\section{b burleigh dodds}




\section{The impact of improving feed efficiency on the environmental impact of livestock production}

James K. Drackley, University of Illinois at Urbana-Champaign, USA; and Christopher K. Reynolds, University of Reading, UK

1 Introduction

2 Greenhouse gases and dairy production

3 Origin of methane and reactive nitrogen excretions

4 Feed conversion efficiency

5 Nutritional practices to enhance feed conversion efficiency and decrease $\mathrm{CH}_{4}$ excretion

6 Nutritional practices to increase milk protein efficiency and decrease $\mathrm{N}_{2} \mathrm{O}$ excretion

7 Genetics and feed conversion efficiency

8 Postabsorptive metabolism and feed conversion efficiency

9 Conclusion

10 Future trends in research

11 Where to look for further information

12 References

\section{Introduction}

As ruminants, cattle are marvellous bioreactors that, through symbiotic rumen fermentation, convert cellulosic plant biomass and other organic materials inedible to humans into high-quality animal proteins for human nutrition. Nevertheless, the conversion is of course not $100 \%$ efficient, and so varying quantities of waste products such as carbon dioxide $\left(\mathrm{CO}_{2}\right)$, methane $\left(\mathrm{CH}_{4}\right)$, and reactive nitrogenous compounds are emitted. As such, producers of ruminant livestock must strive to maximise output for each unit of input, both to enhance enterprise profitability and to minimise the environmental impacts of dairy and meat production. A key metric of this system efficiency is feed conversion efficiency (FCE), which for milk production is usually defined as energy-corrected 
milk divided by feed dry matter intake (DMI) and for meat production is live weight gain divided by feed DMI. FCE per se also has a genetic component, which can be measured by residual feed intake (RFI). RFI is defined as the actual intake minus the feed intake expected to meet requirements for milk production, growth, reproduction and maintenance (Koch et al., 1963).

FCE has been widely used in beef production, as well as in pork and poultry production, to monitor the efficiency of feed utilization for growth. The dairy industry also recognizes the importance of the metric in management systems, but in addition to milk yield, there is also a need to account for body tissue loss and gain in calculating the efficiency of a lactating dairy cow (VandeHaar, 1998). Maximising the output of saleable product per unit of resource input is a standard principle of all manufacturing industries that relate directly to profitability. Another way of stating this relationship is that producers must minimise their unit cost of product and optimise their total unit output (Colman et al., 2011).

Relative to the reduction of greenhouse gases and contaminants of water, the simple concept is that the more carbon and nitrogen $(\mathrm{N})$ in feedstuffs captured in the product, the less carbon and $\mathrm{N}$ are available for conversion into waste products (e.g. $\mathrm{CO}_{2^{\prime}} \mathrm{CH}_{4}$ or urea N). By this principle, increasing milk or meat output from the same feed input requires changes in digestibility or postabsorptive nutrient metabolism with the result that less greenhouse gases and other waste products are produced per unit of milk or meat. The same principles apply to phosphorus and other nutrients that may become pollutants when they escape the animal through feaces or urine. This chapter will focus on the efficiency of milk production by dairy cattle related to nutrition and genetics focussing on how improving FCE can decrease the greenhouse gas burden of milk production and how FCE can be improved.

\section{Greenhouse gases and dairy production}

In the United States during 2008, the dairy sector's contribution to greenhouse gas emissions was estimated to be $134 \mathrm{Tg} \mathrm{CO}_{2}$ equivalents, which equated to $1.9 \%$ of the total U.S. output (Thoma et al., 2013). Of this, $\mathrm{CH}_{4}$, nitrous oxide $\left(\mathrm{N}_{2} \mathrm{O}\right)$, and $\mathrm{CO}_{2}$ contributed $44 \%, 13 \%$, and $41 \%$, respectively, of total emissions of the sector (Thoma et al., 2013). Emissions of $\mathrm{CH}_{4}$ attributed to the dairy sector are primarily enteric emissions arising from digestive tract fermentation and stored manure, whereas $\mathrm{N}_{2} \mathrm{O}$ emissions are largely attributable to $\mathrm{N}$ fertiliser application for the production of feedstuffs and manure application to farm land, including direct deposition by grazing livestock (Uweze et al., 2020; Rotz, 2018). In contrast, direct emissions of $\mathrm{CO}_{2}$ arising from rumen fermentation and animal metabolism are not considered, as these emissions are a consequence of the digestion and metabolism of plant material incorporating atmospheric 
$\mathrm{CO}_{2}$ captured by photosynthesis. These estimates of the contribution of dairy production systems to global greenhouse gas emissions have been revisited recently because of the shorter half-life of $\mathrm{CH}_{4}$ relative to $\mathrm{CO}_{2}$. Methane from ruminants is also derived from the digestion of plant material, and over time $\mathrm{CH}_{4}$ in the atmosphere is converted to $\mathrm{CO}_{2}$, which reduces the long-term global warming effect of enteric $\mathrm{CH}_{4}$ (Cain et al., 2019). In light of these considerations, dairy's contributions to $\mathrm{CO}_{2}$ and $\mathrm{N}_{2} \mathrm{O}$ emissions through fossil fuel consumption, fertilizer production and use, as well as manure management, are a greater concern for global warming in the longer term.

While the dairy sector is a small contributor relative to other industries such as oil and gas, the industry faces pressure to decrease greenhouse gas output. From the viewpoint of dairy producers, this pressure should not be viewed necessarily as burdensome because methane amounts to a 3.8-7.4\% (5.6\% on average) loss of gross energy intake from feeds (Kebreab et al., 2008). Mitigating greenhouse gas emissions should help not only the environment but also the financial bottom line of dairy production, unless the costs of mitigation become excessive. This is true especially if the feed energy not emitted as methane is captured as additional milk or body tissue (Reynolds et al., 2011). However, in most studies to date decreases in methane emission resulting from feeding methane inhibitory compounds such as 3-nitrooxypropanol (Reynolds et al., 2014; Hristov et al., 2015) or nitrate (Olijhoek et al., 2016) have not been associated with increases in milk energy yield or body energy balance. In this case, a part of the energy not emitted as methane is emitted as hydrogen, but the fate of the remainder of the methane energy not emitted is not certain (Olijhoek et al., 2016). In contrast, dietary strategies such as supplemental fat consistently decrease methane per $\mathrm{kg}$ feed DMI and often increase milk yield (Beauchemin and Grainger, 2011), but in this case, the effects on milk yield are through mechanisms independent from the effects on methane emission.

An issue with striving to decrease methane emissions is a decrease relative to what - in other words, what is the denominator of the equation? A reduction in total methane produced by the dairy sector will be difficult to achieve without reductions in animal numbers or effective mitigation strategies (e.g., methaneinhibiting feed supplements). Reductions in methane formation per unit of feed dry matter consumed (methane yield) may require shifts in the microbial community's overall metabolism or methanogenic enzyme inhibition through feed additives such as nitrate (Olijhoek et al., 2016) or 3-nitrooxypropanol (Hristov et al., 2015) as discussed above. Reductions in methane yield can also be achieved by feeding supplemental fat, which provides dietary energy that is not fermented in the rumen to yield hydrogen for methane synthesis (Grainger and Beauchemin, 2011). In contrast, decreases in methane production per unit of milk produced (methane intensity) are possible by boosting production efficiency (milk per unit of feed DMI). Much of this benefit arises from a dilution 
of the greenhouse gas production associated with the maintenance intake of the animal (Knapp et al., 2014). Cows require a certain amount of feed nutrients to maintain critical life functions even in the absence of milk production; think of it as the 'overhead' digestion and metabolism needed to sustain the basic functions of cows. Increasing the amount of milk produced per unit of additional feed intake thus serves to dilute the amount of maintenance greenhouse gas production over a larger number of milk production units. Other ways that improving feed efficiency may decrease methane output per unit of milk produced relate to increasing rates of nutrient passage through the rumen, shifting site of digestion to the intestine, feeding supplemental fat, or reducing heat production by the animal by alterations in metabolism that result in greater milk yield (discussed in a later section).

\section{Origin of methane and reactive nitrogen excretions}

In ruminants, enteric methane is mostly produced by the reduction of $\mathrm{CO}_{2}$ in the rumen and hindgut. Greenhouse gas (primarily methane) output by dairy cattle represents $24.2 \%$ of enteric emissions from livestock (USEPA, 2021). The majority of methane production (ca. 85\%) occurs in the reticulorumen of cattle, with normally only $13 \%$ being produced in the lower gut and rectal emissions constituting only 2-3\% of total animal emissions (Murray et al., 1976; Munoz et al., 2012). Thus, factors relating to feed quality, feed consumption, feed degradation, and ruminal metabolism are paramount for the determination of methane output by dairy cattle.

The rich and extensive microbiota in the rumen constantly degrades complex carbohydrates in the diet (cellulose, hemicellulose, pectin, and starch) and metabolizes the constituent monosaccharides to the principal shortchain or volatile fatty acids (VFA), which are acetate, propionate, and butyrate. Conversion of monosaccharides to VFA generates ATP that can be used to drive nucleic acid and protein biosynthesis, that is, the principal components of new microbial cells. Degradation of feed protein and nonprotein $\mathrm{N}$, including urea $\mathrm{N}$ recycled to the rumen, provides substrates $\left(\mathrm{NH}_{3}\right.$, amino acids, peptides) for microbial amino acid and protein synthesis. Ammonia $\mathrm{N}$ not captured as microbial protein is absorbed, converted to urea $\mathrm{N}$ in the liver, and either recycled to the gastrointestinal tract or excreted in the urine. Urea recycled to the rumen and hindgut is degraded by microbial urease to $\mathrm{CO}_{2}$ and $\mathrm{NH}_{3^{\prime}}$ and the $\mathrm{NH}_{3}$ is either used for microbial protein synthesis or is reabsorbed. Any microbial protein synthesized in the hindgut is excreted as faeces, and microbial protein can account for more than $50 \%$ of faecal non-ammonia $\mathrm{N}$ of lactating dairy cattle (Larsen et al., 2001). Urea $\mathrm{N}$ in urine is very reactive and can be quickly volatilised as $\mathrm{NH}_{3}$, especially when urine is mixed with faeces containing microbial urease. Faecal protein $\mathrm{N}$ is less reactive than urinary 
urea $\mathrm{N}$, but as noted above, can contribute to $\mathrm{N}_{2} \mathrm{O}$ and nitrate losses to the environment, depending on manure management practice.

Methane production serves a critical role within the microbial community. Production of acetate from fibre fermentation is associated with the co-production of $\mathrm{CO}_{2}$ and $\mathrm{H}_{2}$. The partial pressure of $\mathrm{H}_{2}$ must be kept very low in the rumen to avoid poisoning the fermentation, and the primary means of doing so is the conversion of $\mathrm{H}_{2}$ and $\mathrm{CO}_{2}$ to $\mathrm{CH}_{4}$ and $\mathrm{H}_{2} \mathrm{O}$ (Hungate, 1966). The organisms responsible belong to the Archaea, but changes in Archaeal populations correlate only weakly with methane production (Tapio et al., 2017). Rather, methane production is related more to the populations of hydrogenproducing bacteria (Wallace et al., 2017). Production of propionate is not associated with the production of $\mathrm{CO}_{2} \mathrm{Or} \mathrm{H}_{2}$; in fact, propionate uses hydrogen reducing equivalents in its synthesis. Although butyrate production also produces $\mathrm{CO}_{2}$, it uses hydrogen reducing equivalents, so methane formation is not necessary (Hungate, 1966).

A fundamental relationship exists then in the fermentative breakdown of dietary components within the rumen, which can be appreciated by writing a simplified (non-chemically balanced) equation for rumen fermentation:

dietary $\mathrm{C}$ and $\mathrm{N} \rightarrow$ microbial biomass $+\mathrm{VFA}+\mathrm{CO}_{2}+\mathrm{CH}_{4}+\mathrm{H}_{2} \mathrm{O}+\mathrm{NH}_{3}$, heat

From the stand point of microbial growth efficiency, microbes strive to maximise biomass growth at a minimum VFA production, thus capturing as much of the starting feed substrate in new microbial cells as possible. The mixed rumen microbial population is able to generate 3-4 moles of ATP per mole of glucose fermented, which contrasts with simple monoculture fermentations that may generate only 2 moles of ATP (Hungate, 1966). Therefore, as rumen nutritionists, we understand that maximising microbial efficiency in the rumen ultimately leads to improved efficiency of milk production. Another way to think of this relationship is that the more dietary $\mathrm{C}$ and $\mathrm{N}$ we can keep in VFA and microbial protein, the less $\mathrm{CH}_{4}$ and $\mathrm{NO}_{2}$ are released into the environment. Similarly, the more efficiently dietary protein can be converted to milk protein through microbial protein synthesis and the metabolism of absorbed amino acids, the less excess $N$ is excreted in urine and faeces. This idea forms the basis for why improving FCE decreases methane loss and the total greenhouse gas emissions attributable to dairy production.

\section{Feed conversion efficiency}

Improvements in milk production over the last several decades provide a clear demonstration of the benefits of improved FCE. Increases in FCE have arisen from increases in milk production, which dilutes the proportion of feed used for 
maintenance (VandeHaar and St-Pierre, 2006). Milk production has increased from intense genetic selection, improved nutrition and cow health, and other advances in modern management techniques. The improved FCE has benefited dairy producers' profitability, decreased the environmental impact of milk production, reduced the amount of land required for milk production, and decreased the greenhouse gas emission per unit of milk produced (Knapp et al., 2014). Continued gains in FCE by these methods will diminish, however, because the effect diminishes with each increment of dilution of maintenance (VandeHaar, 1998; Reynolds et al., 2011; VandeHaar et al., 2016).

Many environmental factors also affect FCE, including nutrition. Diet digestibility, or more specifically forage digestibility, is a major component of FCE. Dietary protein and carbohydrate balance, supplemental fats and various additives may also impact FCE through effects on digestive function and milk energy yield. Other factors include the stage of lactation, body reserve changes, physical activity, mastitis or other diseases, acidosis and heat and cold stress. From a dairy system standpoint, the total FCE of the farm unit is impacted by numerous factors, including calving interval, days dry, age of first calving, reproductive efficiency, periparturient health disorders, and death loss in calves and heifers. These latter factors centre on the effects of decreased productive days of life for those animals that are not producing milk, or not producing large amounts of milk, but continue to consume the feed.

Herd and Arthur (2009) reviewed the biological basis for differences in RFI for beef cattle. Possible components included feed intake, digestion, metabolism associated with fat and protein deposition, physical activity, thermoregulation, and other components of basal metabolism. As reviewed by Reynolds et al. (2011), digestible energy is the most variable proportion of gross energy intake in ruminants. It accounted for $86 \%$ of the variation in dietary net energy for lactation in dairy cattle in the calorimetry studies on which the initial NEmilk system for energy requirements of lactating dairy cows in the USA was based (Moe et al., 1972). This largely reflects differences in forage quality and the digestibility of fibre, which is affected by forage maturity at harvest and processing during conservation and feeding, as well as associative effects of other diet components that impact the rate and extent of fibrolytic activity in the rumen.

Beever and Drackley (2013) calculated methane production per kilogram of milk production as a function of increasing milk production efficiency and found a negative relationship between the two (Fig. 1). That this theoretical calculation was borne out in practice was demonstrated by an analysis of 323 measurements of methane emission by lactating dairy cows at the University of Reading (Fig. 2). When expressed on the basis of MJ of methane emitted per $\mathrm{MJ}$ of milk energy production, there was a reduction in methane emission 


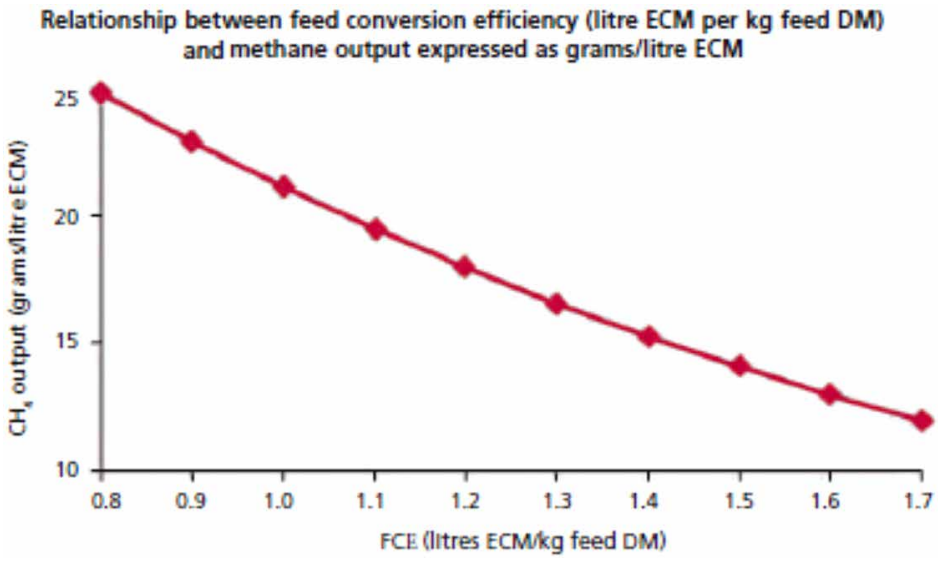

Figure 1 Theoretical relationship between methane output ( $g / L E C M)$ and FCE (L ECM/ kg DM). Reprinted from Beever and Drackley (2013) with permission.

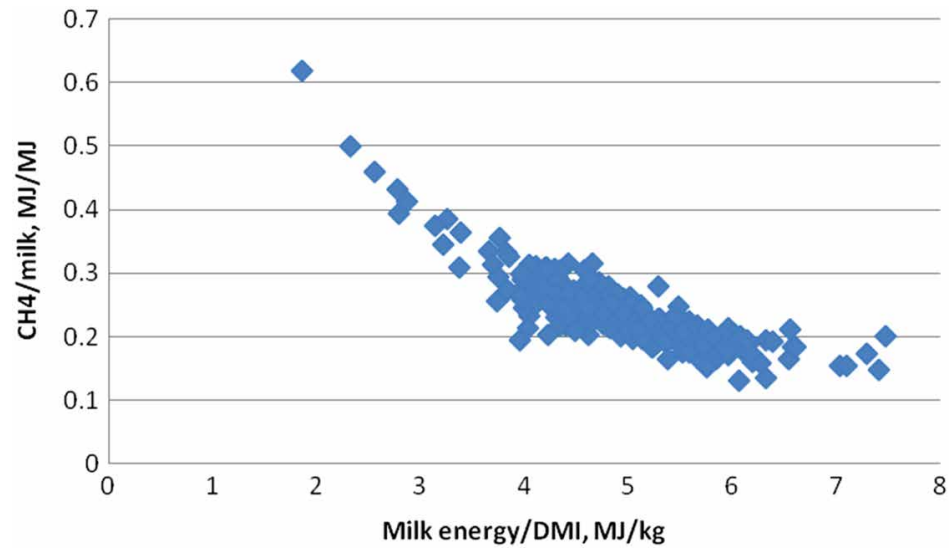

Figure 2 Methane energy/milk energy (MJ/day) as a function of milk energy (MJ/day) per unit feed dry matter intake ( $\mathrm{kg} /$ day) where $y=0.833^{*} \exp ^{(-0.259 * x)}$. Individual observations ( $n$ $=323$ ) for cows fed various dietary treatments in experiments conducted at the University of Reading with correction for the random effect of experiment on the intercept.

per unit milk energy yield with increasing FCE, expressed as milk energy per $\mathrm{kg}$ feed DMI (MJ/kg). An exponential decay curve provided the best fit of the data after correction for the effect of experiment, clearly showing the higher methane 'overhead' of lower-yielding cows and the dilution of maintenance greenhouse gas 'costs' with higher milk yield and FCE. Similar relationships between increased milk yield per se and reduced methane emission per unit milk yield have been noted previously (Reynolds et al., 2011). 


\section{Nutritional practices to enhance feed conversion efficiency and decrease $\mathrm{CH}_{4}$ excretion}

Because methane formation occurs from microbial fermentation of dietary constituents, it follows that nutrition of the ruminant impacts FCE and methane production (Table 1). The most important aspect of nutrition is feed intake, represented in ruminants as DMI. A meta-analysis of methane measurements from growing and lactating cattle (Mills et al., 2009) revealed that feed DMI was the primary predictor of methane emission (Reynolds et al., 2011). The effect of DMI is explained by the increasing provision of fermentable substrates, although the use of digestible energy only marginally improved the prediction (Mills et al., 2009).

A commonly used equation to estimate methane production (Moe and Tyrrell, 1979) is as follows:

methane production, $\mathrm{MJ} / \mathrm{d}=1.837+1.142$ (digested soluble residue, $\mathrm{kg} / \mathrm{d}$ )

$$
\begin{aligned}
& +2.142 \text { (digested hemicellulose, } \mathrm{kg} / \mathrm{d} \text { ) } \\
& +5.828 \text { (digested cellulose, } \mathrm{kg} / \mathrm{d} \text { ). }
\end{aligned}
$$

Since this early work of Moe and Tyrrell (1979), there have been numerous subsequent meta-analyses of measurements of methane emission relative to

Table 1 Feeding management variables and effects on methane $\left(\mathrm{CH}_{4} / \mathrm{ECM}\right)$, dry matter intake (DMI), energy-corrected milk (ECM), and feed conversion efficiency (FCE). Modified from

\begin{tabular}{|c|c|c|c|c|}
\hline Feeding alteration & $\mathrm{CH}_{4} / \mathrm{ECM}$ & DMI & $\mathrm{ECM}$ & FCE \\
\hline Increased DMI & Decrease & Increase & Increase & $\begin{array}{l}\text { Increase or no } \\
\text { change }\end{array}$ \\
\hline $\begin{array}{l}\text { Increased forage } \\
\text { quality }\end{array}$ & Decrease & Increase & Increase & Increase \\
\hline $\begin{array}{l}\text { Decreased forage } \\
\text { particle size }\end{array}$ & No change & Increase & $\begin{array}{l}\text { Increase or no } \\
\text { change }\end{array}$ & No change \\
\hline Grain processing & Decrease & No change & $\begin{array}{l}\text { Increase or no } \\
\text { change }\end{array}$ & $\begin{array}{l}\text { Increase or no } \\
\text { change }\end{array}$ \\
\hline $\begin{array}{l}\text { Increased concentrate } \\
\text { feeding }\end{array}$ & Decrease & Increase & Increase & $\begin{array}{l}\text { Increase or no } \\
\text { change }\end{array}$ \\
\hline Rumen $\mathrm{pH}<5.5$ & Decrease & $\begin{array}{l}\text { No change or } \\
\text { decrease }\end{array}$ & Decrease & Decrease \\
\hline Brown midrib corn & Decrease & Increase & Increase & $\begin{array}{l}\text { Increase or no } \\
\text { change }\end{array}$ \\
\hline Fat feeding & Decrease & $\begin{array}{l}\text { Decrease or no } \\
\text { change }\end{array}$ & Increase & Increase \\
\hline
\end{tabular}
Knapp et al. (2014) 
diet intake and composition, which have largely confirmed the overriding role of intake of digestible structural and nonstructural carbohydrates, as well as lipids (see below), in determining methane emission and yield. For example, a recent global analysis of 3183 individual observations concluded that prediction models should include diet intake, digestibility, and concentrations of structural and nonstructural carbohydrates and ether extract for greatest accuracy (Benaouda et al., 2019).

According to Equation 2, increments of digested soluble residue, largely comprising starch and sugars, will increase methane to a lesser extent than digested hemicellulose or cellulose from forages. In turn, digested hemicellulose has a much smaller effect than digested cellulose. This is consistent with the fact that starch fermentation yields a greater proportion of propionate compared to fibre fermentation (Hungate, 1966). Increasing concentrate supplementation in the diet increases digestible energy, usually increases FCE, and decreases methane output per unit of milk produced, as predicted by the analysis in Fig. 2 and by the diluting effect of greater productivity on methane production per unit of milk yield. Concentrates containing cereal grains rich in starch will increase the metabolisable energy available to the animal, usually increasing milk yield unless excessive amounts are fed that cause acidosis (Van Soest, 1994).

In contrast, increasing the digestibility of forages, which will usually increase FCE by boosting milk yield, might not reliably change methane production per unit of milk produced because of the increase of fermented cellulose and hemicellulose. However, in practice, improving forage digestibility usually increases FCE and, by increasing milk production, the yield of methane per unit of ECM decreases due to the dilution of the maintenance concept. Variations in concentrations of cellulose, hemicellulose, and starch, as well as their digestibility, interact with differences in DMI that can make it difficult to predict the resulting methane production from differences in FCE (Reynolds et al., 2010; Livingstone et al., 2015). For example, diets higher in maize silage contained more starch and less NDF than diets higher in grass silage, and resulted in greater DMI and milk yields, but FCE was greater for the diets high in grass silage. However, methane intensity was greater for the high grass silage diets (Hammond et al., 2016).

Forage digestibility can be increased in several ways. Harvesting at younger maturity increases digestibility because of greater concentrations of nonstructural carbohydrates, such as sugars and fructans, along with lower lignification of plant cell walls (Van Soest, 1994). Some genetic variants have greater digestibility. For example, the stover from the bm-3 or brown midrib genetic variant of maize and sorghum is more highly digested than typical varieties (Oba and Allen, 2000). Cellulose, hemicellulose, and NDF were less digestible in diets containing $40 \%$ (DM) maize silage and $10 \%$ alfalfa silage 
than in diets containing $10 \%$ maize silage and $40 \%$ alfalfa silage (Ruppert et al., 2003). Finally, grass forage is typically more digestible than legumes, such as alfalfa, although the rate of fermentation is faster for legumes (Van Soest, 1994).

Processing forages can have contradictory effects on methane yield. Fine grinding or pelleting of forage increases the surface area available for fibrolytic microbiota to attach for fermentation, but the small particle size increases its passage from the rumen (Russell and Hespell, 1981), thus limiting the digested dry matter and so limiting methane formation (Moss et al., 2000). Such effects could decrease methane by $20-40 \%$ per unit of DM at high intakes, although at restricted intakes the effects are less (Johnson and Johnson, 1995). However, this also decreases potential energy delivery to the animal, which might decrease milk production, although compensatory hindgut digestion can recover some of the lost energy (Van Soest, 1994). With fine grinding of the forage and the resulting faster passage, however, the animal will likely eat more (Van Soest, 1994), which would tend to increase methane production.

Grains can be processed by grinding, rolling, and steam flaking, all of which increase surface area for digestion and decrease particle size. Grain processing can decrease the amount of starch that passes to the small intestine. Digestion in the small intestine should be more efficient energetically, but results have not borne this out in practice (Huntington et al., 2006). The effect of processing on ruminal degradation of starch varies among cereals and depends on the processing methods used (Svihus et al., 2005). Extensive rolling of barley maximised ruminal and postruminal digestion of starch (Yang et al., 2001). More extreme processing tends to increase total VFA concentration in the rumen, with a greater proportion of propionate that would decrease methane formation. Grinding maize grain increased starch digestibility in the total tract compared with rolling (Knowlton et al., 1998), but ground maize resulted in greater methane production (Wilkerson et al., 1997). Steam flaking maize grain resulted in greater FCE than grinding, regardless of particle size of grind (Ahmadi et al., 2020). However, finely ground maize can produce results similar to steam-flaked maize (Mathew et al., 2011). Heat treatment through pelleting, flaking, extruding, and toasting can change the ruminal degradation rates of protein and carbohydrates and decrease the acetate:propionate ratio in the rumen (Van Nevel and Demeyer, 1996). However, the relationship between such treatments and $\mathrm{CH}_{4}$ emissions depends on the feed, composition of the total diet, and intake (Knapp et al., 2014).

Supplemental fats and oils are often added to diets for dairy cattle to increase the energy density of diets for high milk production (Palmquist and Jenkins, 2017). According to meta-analyses (Rabiee et al., 2012; Hu et al., 2017), fats usually maintain or decrease DMI while increasing milk yield and milk energy output. Consequently, supplemental fat sources often increase FCE and, as expected, decrease methane output per unit of milk energy (Ruppert 
et al., 2003; Kliem et al., 2019). The effect of lipids on methane production is dependent on the source, fatty acid profile, inclusion rate, form of lipid, and diet composition (Beauchemin et al., 2008). Lipid sources replace fermentable substrates, and the unsaturated fatty acids provide an alternate sink for hydrogen disposal. Unsaturated fatty acids also directly impact fibre-fermenting microbiota and methanogens in the rumen (Czerkawski et al., 1966; Blaxter and Czerkawski, 1966). In practice, however, changes in methane production are not always observed. Nevertheless, a meta-analysis conducted by Knapp et al. (2014) found that increasing fat content of the diet decreased methane per unit of ECM, and that the type of lipid source affected the response. Free vegetable oils and endogenous lipids resulted in a greater reduction of methane per unit of ECM than did inert fats or seed lipids. Some seeds, vegetable oils, and medium-chain fatty acids (such as those found in coconut oil; Hristov et al., 2009) further decrease methane, but often at the expense of DMI, which could be detrimental to productivity and reproduction over the long term (Reynolds et al., 2011; Knapp et al., 2014).

In addition to 3-nitrooxypropanol and nitrate mentioned previously, a variety of potential nutritional additives have been tested for their ability to improve FCE and decrease methane losses, including ionophores, yeasts, certain seaweeds, and plant bioactive compounds with antimicrobial or digestive effects, such as tannins and essential oils (Beauchemin et al., 2008; McAllister and Newbold, 2008). These compounds have had varying efficacies, especially in the longer term, perhaps due to differences in dose rate and adaptation of the rumen microbes (Beauchemin et al., 2008). Although some have shown potential to decrease methane excretion, for these approaches to be widely adopted their effects will need to be consistent, sustained, without deleterious effects on feed intake, production, FCE or product quality, economic to adopt, and sustainable (Reynolds et al., 2011).

\section{Nutritional practices to increase milk protein efficiency and decrease $\mathrm{N}_{2} \mathrm{O}$ excretion}

In ruminant production systems, enteric $\mathrm{CH}_{4}$ production is the greatest contributor to greenhouse gas emissions, followed by $\mathrm{CH}_{4}$ from manure and in beef feedlot systems, $\mathrm{N}_{2} \mathrm{O}$ from pen surfaces, and $\mathrm{N}_{2} \mathrm{O}$ emissions from soils (Montes et al., 2013). Improving the efficiency of dietary $N$ use by increasing $N$ incorporation into milk protein and decreasing $\mathrm{N}$ losses in faeces and urine will have positive effects on $\mathrm{N}_{2} \mathrm{O}$ excretion and environmental contamination with $N$ (Uwizeye et al., 2020). Many of the same principles discussed to this point relative to increasing FCE will have beneficial effects on increasing efficiency of dietary $\mathrm{N}$ use. From an environmental standpoint, animal practices to decrease urinary $\mathrm{N}$ loss have the biggest impact because urinary $\mathrm{N}$ is more susceptible 
to leaching and volatile losses than faecal $\mathrm{N}$ and contributes directly to $\mathrm{N}_{2} \mathrm{O}$ loss from livestock facility surfaces (Dijkstra et al., 2013a; Montes et al., 2013).

The main driver of $\mathrm{N}$ losses from cattle is $\mathrm{N}$ consumed in feed. Dairy cows secrete in milk an average of 21-33\% of consumed N (Calsamiglia et al., 2010), with almost all the remaining $\mathrm{N}$ excreted in faeces and urine. In agreement, Reed et al. (2015) calculated an average total manure $\mathrm{N}$ excretion of $69 \%$ of $\mathrm{N}$ intake from a large database. Dijkstra et al. (2013b) calculated the theoretical upper limit of dietary $N$ incorporation into milk protein to be $43 \%$ at maximal milk secretion for a cow weighing $650 \mathrm{~kg}$ and producing $40 \mathrm{~kg} /$ day of fat and protein corrected milk.

Huhtanen and Hristov (2009) concluded from a meta-analysis that dietary crude protein (CP) concentration is the most important dietary factor influencing milk $\mathrm{N}$ efficiency, with ruminal degradation of CP being of lesser importance. Differences in amount and, to a smaller extent, digestibility of $\mathrm{N}$ in feed affect not only the total amount excreted but also the partitioning of $\mathrm{N}$ among milk, urine, and faeces (Castillo et al., 2001; Kebreab et al., 2002). Partitioning of manure N excretion into faecal and urinary $\mathrm{N}$ excretion is important because differences in $\mathrm{N}$ intake largely affect urinary $\mathrm{N}$ output, which is of greater importance to reduce environmental impact (Dijkstra et al., 2013a).

The carbohydrate portion of the diet may impact the efficiency of dietary $N$ use through differences in the amount or efficiency of $\mathrm{N}$ capture in the rumen. Ruminants must have sufficient ruminally degradable protein to maximise fermentation with the amount of fermentable carbohydrates supplied. Wilkinson and Garnsworthy (2017) showed that replacing dietary grazed grass or grass silage with corn silage at similar milk yield increased $\mathrm{N}$ efficiency and reduced the C footprint. Grazed grass is particularly problematic in terms of urinary $N$ loss because of the high soluble CP content of the grass and concurrent lower content of rapidly fermentable carbohydrates (Hristov et al., 2013).

Dairy producers have often overfed dietary protein in the mistaken assumption that it would boost milk production (Broderick, 2018). Broderick (2003) compared diets with CP increasing from $15.1 \%$ to $16.7 \%$ and $18.4 \%$ by adding soya meal to the diet. Milk and milk protein yields increased with the first increment of CP but not the second. The only result from increasing dietary CP to $18.4 \%$ was the increased excretion of urinary $N$, which accounted for nearly all of the increment of dietary N. Recently, a trend for lower dietary CP has been observed in high-producing herds. Diets with as little as $14.9 \%$ CP can support milk production in excess of $45 \mathrm{~kg} /$ day when properly balanced for $\mathrm{N}$ and carbohydrate fractions and supplemented with key ruminally protected amino acids (Fessenden et al., 2020). In 2010, the five highest producing herds in the state of Wisconsin were being fed diets containing an average of $16.9 \%$ dietary CP, with the lowest at 16.3\% (Broderick, 2018). Over the period from 2004 to 2010, CP content of dairy diets in Wisconsin decreased 1.1 percentage units, 
but milk and protein production increased by 1700 and $51 \mathrm{~kg}$ per lactation. Clearly, minimising dietary CP needed to support high milk production pays dividends in the way of decreasing ration cost and environmental excretion of $\mathrm{N}$, without sacrificing productivity.

\section{Genetics and feed conversion efficiency}

Using RFI as a measure of FCE has the advantage that it is independent of maintenance requirements and is not an efficiency determined by the level of production per se. A disadvantage of the measurement is that animals that are more efficient have negative $\mathrm{RFI}$, which is non-intuitive and difficult for producers to accept. Reported heritability estimates of RFI in dairy cattle generally are low to moderate, with estimates ranging from 0.01 to 0.40 among lactating cows (Connor, 2015). Tempelman et al. (2015) determined that RFI had a heritability of $0.15-0.18$. This means that the trait could be improved through genetic selection but that much of the variation in phenotype must be attributable to other environmental factors. Genetic correlations suggest no undesirable relationships detected between RFI and fat-corrected milk yield, productive life or feeding behaviours, and desirable relationships between RFI and predicted methane production in lactating cows (Connor, 2015).

There is currently interest in the potential selection of dairy cattle for improved feed efficiency (e.g. Lin et al., 2013; VandeHaar et al., 2020) and lower methane emission or methane yield (e.g. Breider et al., 2019; Lassen and Løvendahl, 2016). However, these traits must not be considered in isolation; for example, reductions in methane yield in sheep were shown to be driven by higher rates of feed passage through the rumen attributable to smaller rumen volume and thus reduced total feed intake capacity (Goopy et al., 2013).

The benefits of selection for RFI make the prospect of its application promising. For example, Holstein-Friesian heifers in New Zealand and Australia fed a forage-based diet that were in the bottom $10 \%$ of the sample population for RFI (i.e. most efficient) consumed 15\%-20\% less feed relative to heifers in the top $10 \%$ for RFI (least efficient; Williams et al., 2011; Waghorn et al., 2012). Differences are similar to differences in DMI of $12-13 \%$ reported in low versus high RFI groups of growing Angus-Hereford steers (Cruz et al., 2010). The dairy heifers cited showed no differences in feed intake, yields of milk or milk components, change in BW or body condition score when evaluated during days 75-195 of their first lactation (Macdonald et al., 2014). These results indicate that considerable savings in feed costs can be achieved by maintaining only the most feed-efficient growing heifers in the herd, with no negative consequences on future lactation performance.

In addition to selection for RFI, it might be possible to use genetic selection to improve $\mathrm{N}$ efficiency. Marshall et al. (2020) used breeding values for milk 
urea N (MUN) to create high and low lines of Holstein-Friesian dairy cows. There was a positive relationship between MUN breeding value and MUN, with MUN decreasing $1.61 \mathrm{mg} / \mathrm{dL}$ per unit decrease in MUN breeding value. Urinary $\mathrm{N}$ concentration decreased $0.67 \mathrm{~g} / \mathrm{L}$ per unit decrease of MUN breeding value, with no difference in urine volume or urinary frequency, which resulted in a 165 $\mathrm{g} /$ day decrease in urinary urea $\mathrm{N}$ excretion between animals with the highest and lowest MUN breeding value. At the same milkyield, milk protein percentage increased by 0.09 per unit of MUN breeding value. Such preliminary results are positive both for decreasing environmental excretion of $\mathrm{N}$ and for improving $\mathrm{N}$ partitioning into milk for greater producer profitability.

Relative to greenhouse gas emissions, cattle with lower RFI have a lower DMI than less efficient animals at similar production levels (Connor, 2015), thus decreasing one major contributor to $\mathrm{CH}_{4}$ production. By definition, animals with lower RFI have less manure output for a given level of production, which should decrease the release of $\mathrm{CH}_{4}$ and $\mathrm{N}_{2} \mathrm{O}$ from stored manure (Montes et al., 2013). Recent research demonstrated that cows with greater FCE (lower RFI) also used protein more efficiently, which would help reduce $\mathrm{N}$ excretion in urine (Liu and VandeHaar, 2020).

\section{Postabsorptive metabolism and feed conversion efficiency}

Heat energy lost in the conversion of ME to net energy (NE) typically accounts for $20-30 \%$ of gross energy intake in dairy cattle. But, in contrast to digestibility, the variation and opportunities to decrease these losses are more limited. The effects of forage type, processing, and forage to concentrate ratio on the efficiency of ME utilisation for milk and meat production (and FCE) have been extensively researched (Reynolds, 2011). Such effects are a greater concern in extensive systems relying heavily on poorer quality forages. Because the digestive system and liver account for as much as $50 \%$ of body heat production in ruminants, their metabolism has an impact on the partial efficiency of ME use for production that is disproportionate to their mass. Forage amount and digestibility impact ME utilisation for $\mathrm{NE}$, which is largely attributable to the tissues of the gut and may reflect differences in the work of digestion and gut mass (McLeod and Baldwin, 2000). In contrast, nutrient re-partitioning agents such as growth hormone impact energy utilisation by altering metabolism in the muscle, adipose tissue, and mammary gland to increase milk production, which improves FCE by dilution of maintenance.

Reducing losses of dietary energy as heat may be one of the main factors affected by selection for improved RFI. Only $19 \%$ of the variation in RFI among animals may be attributable to differences in diet digestion and heat of fermentation, with the remainder likely due to differences in physical activity, 
body composition, protein turnover, and other metabolic processes associated with maintenance requirements and partitioning of nutrients between protein and lipid deposition (Herd and Arthur, 2009).

The effects of excess protein on energy utilisation in cattle have generated much discussion. Tyrrell et al. (1970) reviewed results of calorimetry studies and reported a reduction in $\mathrm{ME}$ or NE of diets when digestible protein was fed in excess of requirements. This effect was included in the calculation of NE for lactation (Moe et al., 1972). Some have attributed this effect of excess protein to the energy costs of urea synthesis in the liver, but studies in sheep and cattle catheterised for measurements of liver metabolism have consistently failed to show an effect of increased ammonia absorption and subsequent urea production by the liver on hepatic oxygen consumption (Reynolds, 2006). In contrast, supplemental protein fed in excess of requirement does increase liver oxygen use (i.e. heat production), as well as oxygen use by the gut, suggesting that the effect of excess protein on the efficiency of energy utilisation is associated with amino acid catabolism, rather than urea synthesis per se (Reynolds, 2006). Over 100 years ago, Rubner showed that the postprandial rise in heat production in dogs, termed 'specific dynamic action', associated with consumption of protein was greater than for carbohydrates and fats (Brody, 1939), which also reflects the catabolism of amino acids in excess of requirements. These effects might be attributable to stimulation of protein turnover and greater activation of the sympathetic nervous system. Regardless of the mechanism, the potential benefits of feeding protein and ruminally protected amino acids more precisely to cattle extend beyond just the environment and economics to improving FCE.

\section{Conclusion}

Methane intensity of dairy production is related inversely to FCE. By diluting methane associated with cow maintenance, increasing milk production and increased FCE serve to decrease methane production per unit of milk energy produced. Nutritional practices that boost productivity usually boost FCE and will help to decrease methane intensity. Some of these include improving forage quality, increasing concentrate supplementation, and using supplemental fats and oils. Genetic selection for improved FCE (measured by RFI) will decrease methane intensity. Minimising dietary CP will help decrease urinary $\mathrm{N}$ losses, which contribute to increased $\mathrm{N}_{2} \mathrm{O}$ and decreased efficiency of $\mathrm{N}$ capture into milk protein.

\section{Future trends in research}

Increasing FCE is directly related to profitability and will be a continued goal of research for improvement in the dairy industry. Decreased methane intensity 
should be a collateral benefit of such improvement. Determining the genetic basis for $\mathrm{FCE}$, as measured by $\mathrm{RFI}$, may eventually lead to improvements in the overall efficiency of milk production. Improving genetic aspects of forage digestibility and methods to improve use by cows will help decrease methane intensity. The research will continue to find compounds or strategies that will decrease methane yield without compromising DMI or productive efficiency. Novel mitigation strategies might include inhibitors or early life microbial modulation to change the balance between hydrogen producers and methanogens. In addition, the possibility that synergistic effects between strategies might occur, such as combining 3-nitrooxypropanol with lipids, should be investigated. Research will continue to identify genetic opportunities to minimise the environmental burden of livestock production as well as urinary $\mathrm{N}$ excretion.

\section{Where to look for further information}

A comprehensive discussion of strategies to mitigate methane emissions in dairy cattle can be found in Knapp, J. R., Laur, G. L., Vadas, P. A., Weiss, W. P., and Tricarico, J. M. (2014), 'Invited review: Enteric methane in dairy cattle production: Quantifying the opportunities and impact of reducing emissions', J. Dairy Sci., 97, 3231-3261.

\section{References}

Ahmadi, F., Ghorbani, G. R., Sadeghi-Sefidmazgi, A., Heydari, M., Rafiee, H. and Beauchemin, K. A. (2020). Performance and feeding behavior of dairy cows fed highconcentrate diets containing steam-flaked or ground corn varying in particle size, $J$. Dairy Sci. 103(4), 3191-3203.

Beauchemin, K. A., Kreuzer, M., O'Mara, F. and McAllister, T. A. (2008). Nutritional management for enteric methane abatement: a review, Aust. J. Exp. Agric. 48(2), 21-27.

Beever, D. E. and Drackley, J. K. (2013). Feeding for optimal rumen and animal health and optimal feed conversion efficiency: the importance of physical nutrition. In: Makkar, H. P. S. and Beever, D. (Eds), Optimization of Feed Use Efficiency in Ruminant Production Systems. Proceedings of the FAO Symposium, 27 November 2012, Bangkok, Thailand, FAO Animal Production and Health Proceedings, No. 16. Rome: FAO and Asian-Australasian Association of Animal Production Societies, pp. 75-92.

Benaouda, M., Martin, C., Li, X., Kebreab, E., Hristov, A. N., Yu, Z., Yáñez-Ruiz, D. R., Reynolds, C. K., Crompton, L. A., Dijkstra, J., Bannink, A., Schwarm, A., Kreuzer, M., McGee, M., Lund, P., Hellwing, A. L. F., Weisbjerg, M. R., Moate, P. J., Bayat, A. R., Shingfield, K. J., Peiren, N. and Eugène, M. (2019). Evaluation of the performance of existing mathematical models predicting enteric methane emissions from ruminants: animal categories and dietary mitigation strategies, Anim. Feed Sci. Technol. 255, 114207. 
Blaxter, K. L. and Czerkawski, J. (1966). Modifications of methane production of the sheep by supplementation of its diet, J. Sci. Food Agric. 17(9), 417-421.

Breider, I. S., Wall, E. and Garnsworthy, P. C. (2019). Short communication: heritability of methane production and genetic correlations with milk yield and body weight in Holstein-Friesian dairy cows, J. Dairy Sci. 102(8), 7277-7281.

Broderick, G. A. (2003). Effects of varying dietary protein and energy levels on the production of lactating dairy cows, J. Dairy Sci. 86(4), 1370-1381.

Broderick, G. A. (2018). Review: optimizing ruminant conversion of feed protein to human food protein, Animal 12(8), 1722-1734.

Brody, S. (1939). Factors influencing the apparent energetic efficiency of productive processes in farm animals, J. Nutr. 17(3), 235-251.

Cain, M., Lynch, J., Allen, M. R., Fuglestvedt, J. S., Frame, D. J. and Macey, A. H. (2019). Improved calculation of warming-equivalent emissions for short-lived climate pollutants, NPJ Clim. Atmos. Sci. 2, 29.

Calsamiglia, S., Ferret, A., Reynolds, C. K., Kristensen, N. B. and van Vuuren, A. M. (2010). Strategies for optimizing nitrogen use by ruminants, Animal 4(7), 1184-1196.

Castillo, A. R., Kebreab, E., Beever, D. E., Barbi, J. H., Sutton, J. D., Kirby, H. C. and France, J. (2001). The effect of protein supplementation on nitrogen utilization in lactating dairy cows fed grass silage diets, J. Anim. Sci. 79(1), 247-253.

Colman, D. R., Beever, D. E., Jolly, R. W. and Drackley, J. K. (2011). Commentary: Gaining from technology for improved dairy cow nutrition: economic, environmental, and animal health benefits, Prof. Anim. Sci. 27(6), 505-517.

Connor, E. E. (2015). Invited review: improving feed efficiency in dairy production: challenges and possibilities, Animal 9(3), 395-408.

Cruz, G. D., Rodríguez-Sánchez, J. A., Oltjen, J. W. and Sainz, R. D. (2010). Performance, residual feed intake, digestibility, carcass traits, and profitability of Angus-Hereford steers housed in individual or group pens, J. Anim. Sci. 88(1), 324-329.

Czerkawski, J. W., Blaxter, K. L. and Wainman, F. W. (1966). The effect of linseed oil and of linseed oil fatty acids incorporated in the diet on the metabolism of sheep, Br. J. Nutr. 20(3), 485-494.

Dijkstra, J., Oenema, O., van Groenigen, J. W., Spek, J. W., van Vuuren, A. M. and Bannink, A. (2013a). Diet effects on urine composition of cattle and N2O emissions, Animal 7 (Suppl. 2), 292-302.

Dijkstra, J., Reynolds, C. K., Kebreab, E., Bannink, A., Ellis, J. L., France, J. and van Vuuren, A. M. (2013b). Challenges in ruminant nutrition: towards minimal nitrogen losses in cattle. In: Oltjen, J. W., Kebreab, E. and Lapierre, H. (Eds) Energy and Protein Metabolism and Nutrition in Sustainable Animal Production. Wageningen, The Netherlands: Wageningen Academic Publishers, pp. 47-58.

Fessenden, S. W., Ross, D. A., Block, E. and Van Amburgh, M. E. (2020). Comparison of milk production, intake, and total-tract nutrient digestion in lactating dairy cattle fed diets containing either wheat middlings and urea, commercial fermentation by-product, or rumen-protected soybean meal, J. Dairy Sci. 103(6), 5090-5101.

Goopy, J. P., Donaldson, A., Hegarty, R., Vercoe, P. E., Haynes, F., Barnett, M. and Oddy, V. H. (2013). Low-methane yield sheep have smaller rumens and shorter rumen retention time, Br. J. Nutr. 111(4), 578-585.

Grainger, C. and Beauchemin, K. A. (2011). Can enteric methane emissions from ruminants be lowered without lowering their production?, Anim. Feed Sci. Technol. 166-167, 308-320. 
Hammond, K. J., Jones, A. K., Humphries, D. J., Crompton, L. A. and Reynolds, C. K. (2016). Effects of diet forage source and neutral detergent fiber content on milk production of dairy cattle and methane emissions determined using GreenFeed and respiration chamber techniques, J. Dairy Sci. 99(10), 7904-7917.

Herd, R. M. and Arthur, P. F. (2009). Physiological basis for residual feed intake, J. Anim. Sci. 87(14) (Suppl.), E64-E71.

Hristov, A. N., Oh, J., Giallongo, F., Frederick, T. W., Harper, M. T., Weeks, H. L., Branco, A. F., Moate, P. J., Deighton, M. H., Williams, S. R. O., Kindermann, M. and Duval, S. (2015). An inhibitor persistently decreased enteric methane emission from dairy cows with no negative effect on milk production, Proc. Natl. Acad. Sci. U. S. A. 112(34), 10663-10668.

Hristov, A. N., Ott, T., Tricarico, J., Rotz, A., Waghorn, G., Adesogan, A., Dijkstra, J., Montes, F., Oh, J., Kebreab, E., Oosting, S. J., Gerber, P. J., Henderson, B., Makkar, H. P. and Firkins, J. L. (2013). Special topics - Mitigation of methane and nitrous oxide emissions from animal operations: III. A review of animal management mitigation options, J. Anim. Sci. 91(11), 5095-5113.

Hristov, A. N., Vander Pol, M., Agle, M., Zaman, S., Schneider, C., Ndegwa, P., Vaddella, V. K., Johnson, K., Shingfield, K. J. and Karnati, S. K. (2009). Effect of lauric acid and coconut oil on ruminal fermentation, digestion, ammonia losses from manure, and milk fatty acid composition in lactating cows, J. Dairy Sci. 92(11), 5561-5582.

$\mathrm{Hu}$, W., Boerman, J. P. and Aldrich, J. M. (2017). Production responses of Holstein dairy cows when fed supplemental fat containing saturated free fatty acids: a metaanalysis, Asian-Australas. J. Anim. Sci. 30(8), 1105-1116.

Huhtanen, P. and Hristov, A. N. (2009). A meta-analysis of the effects of dietary protein concentration and degradability on milk protein yield and milk $\mathrm{N}$ efficiency in dairy cows, J. Dairy Sci. 92(7), 3222-3232.

Hungate, R. E. (1966). The Rumen and Its Microbes. New York: Academic Press.

Huntington, G. B., Harmon, D. L. and Richards, C. J. (2006). Sites, rates, and limits of starch digestion and glucose metabolism in growing cattle, J. Anim. Sci. 84 (Suppl.), E14-E24.

Johnson, K. A. and Johnson, D. E. (1995). Methane emissions from cattle, J. Anim. Sci. 73(8), 2483-2492.

Kebreab, E., France, J., Mills, J. A. N., Allison, R. and Dijkstra, J. (2002). A dynamic model of $\mathrm{N}$ metabolism in the lactating dairy cow and an assessment of impact of $\mathrm{N}$ excretion on the environment, J. Anim. Sci. 80(1), 248-259.

Kebreab, E., Johnson, K. A., Archibeque, S. L., Pape, D. and Wirth, T. (2008). Model for estimating enteric emissions from United States dairy and feedlot cattle, J. Anim. Sci. 86(10), 2738-2748.

Kliem, K. E., Humphries, D. J., Kirton, P., Givens, D. I. and Reynolds, C. K. (2019). Differential effects of oilseed supplements on methane production and milk fatty acid concentrations in dairy cows, Animal 13(2), 309-317.

Knapp, J. R., Laur, G. L., Vadas, P. A., Weiss, W. P. and Tricarico, J. M. (2014). Invited review: enteric methane in dairy cattle production: quantifying the opportunities and impact of reducing emissions, J. Dairy Sci. 97(6), 3231-3261.

Knowlton, K. F., Glenn, B. P. and Erdman, R. A. (1998). Performance, ruminal fermentation, and site of starch digestion in early lactation cows fed corn grain harvested and processed differently, J. Dairy Sci. 81(7), 1972-1984.

Koch, R. M., Swiger, L. A., Chambers, D. and Gregory, K. E. (1963). Efficiency of feed use in beef cattle, J. Anim. Sci. 22(2), 486-494. 
Larsen, M., Madsen, T. G., Weisbjerg, M. R., Hvelplund, T. and Madsen, J. (2001). Small intestinal digestibility of microbial and endogenous amino acids in dairy cows, $J$. Anim. Physiol. Anim. Nutr. (Berl.) 85(1-2), 9-21.

Lassen, J. and Løvendahl, P. (2016). Heritability estimates for enteric methane emissions from Holstein cattle measured using noninvasive methods, J. Dairy Sci. 99(3), 1959-1967.

Lin, Z., Macleod, I. and Pryce, J. E. (2013). Short communication: estimation of genetic parameters for residual feed intake and feeding behavior traits in dairy heifers', $J$. Dairy Sci. 96(4), 2654-2656.

Liu, E. and VandeHaar, M. J. (2020). Relationship of residual feed intake and protein efficiency in lactating cows fed high- or low-protein diets, J. Dairy Sci. 103(4), 3177-3190.

Livingstone, K. M., Humphries, D. J., Kirton, P., Kliem, K. E., Givens, D. I. and Reynolds, C. K. (2015). Effects of forage type and extruded linseed supplementation on methane production and milk fatty acid composition of lactating dairy cows, J. Dairy Sci. 98(6), 4000-4011.

Macdonald, K. A., Pryce, J. E., Spelman, R. J., Davis, S. R., Wales, W. J., Waghorn, G. C., Williams, Y. J., Marett, L. C. and Hayes, B. J. (2014). Holstein-Friesian calves selected for divergence in residual feed intake during growth exhibited significant but reduced residual feed intake divergence in their first lactation, J. Dairy Sci. 97(3), 1427-1435.

Marshall, C. J., Beck, M. R., Garrett, K., Barrell, G. K., Al-Marashdeh, O. and Gregorini, P. (2020). Grazing dairy cows with low milk urea nitrogen breeding values excrete less urinary urea nitrogen, Sci. Total Environ. 739, 139994.

Mathew, B., Eastridge, M. L., Oelker, E. R., Firkins, J. L. and Karnati, S. K. R. (2011). Interactions of monensin with dietary fat and carbohydrate components on ruminal fermentation and production responses by dairy cows, J. Dairy Sci. 94(1), 396-409.

McAllister, T. A. and Newbold, C. J. (2008). Redirecting rumen fermentation to reduce methanogenesis, Aust. J. Exp. Agric. 48(2), 7-13.

McLeod, K. R. and Baldwin, R. L. 6th. (2000). Effects of diet forage:concentrate ratio and metabolizable energy intake on visceral organ growth and in vitro oxidative capacity of gut tissues in sheep, J. Anim. Sci. 78(3), 760-770.

Mills, J. A. N., Crompton, L. A., Bannink, A., Tamminga, S., Moorby, J. and Reynolds, C. K. (2009). Predicting methane emissions and nitrogen excretion from cattle, J. Agric. Sci. 147, 741.

Moe, P. W., Flatt, W. P. and Tyrrell, H. F. (1972). Net energy value of feeds for lactation, J. Dairy Sci. 55(7), 945-958.

Moe, P. W. and Tyrrell, H. F. (1979). Methane production in dairy cows, J. Dairy Sci. 62(10), 1583-1586.

Montes, F., Meinen, R., Dell, C., Rotz, A., Hristov, A. N., Oh, J., Waghorn, G., Gerber, P. J., Henderson, B., Makkar, H. P. S. and Dijkstra, J. (2013). Mitigation of methane and nitrous oxide emissions from animal operations: Il. A review of manure management options, J. Anim. Sci. 91(11), 5070-5094.

Moss, A. R., Jouany, J. P. and Newbold, J. (2000). Methane production by ruminants: its contribution to global warming, Ann. Zootech. 49(3), 231-253.

Munoz, C., Yan ,T., Wills, D. A., Murray, S. and Gordon, A. W. (2012). Comparison of the sulfur hexafluoride tracer and respiration chamber techniques for estimating methane emissions and correction for rectum methane output from dairy cows, $J$. Dairy Sci. 95(6), 3139-3148. 
Murray, R. M., Bryant, A. M. and Leng, R. A. (1976). Rates of production of methane in rumen and large-intestine of sheep, Br. J. Nutr. 36(1), 1-14.

Oba, M. and Allen, M. S. (2000). Effects of brown midrib 3 mutation in corn silage on productivity of dairy cows fed two concentrations of dietary neutral detergent fiber: 3. Digestibility and microbial efficiency, J. Dairy Sci. 83(6), 1350-1358.

Olijhoek, D. W., Hellwing, A. L. F., Brask, M., Weisbjerg, M. R., Højberg, O., Larsen, M. K., Dijkstra, J., Erlandsen, E. J. and Lund, P. (2016). Effect of dietary nitrate level on enteric methane production, hydrogen emission, rumen fermentation, and nutrient digestibility in dairy cows, J. Dairy Sci. 99(8), 6191-6205.

Palmquist, D. L. and Jenkins, T. C. (2017). A 100-year Review: fat feeding of dairy cows, J. Dairy Sci. 100(12), 10061-10077.

Rabiee, A. R., Breinhild, K., Scott, W., Golder, H. M., Block, E. and Lean, I. J. (2012). Effect of fat additions to diets of dairy cattle on milk production and components: a metaanalysis and meta-regression, J. Dairy Sci. 95(6), 3225-3247.

Reed, K. F., Moraes, L. E., Casper, D. P. and Kebreab, E. (2015). Predicting nitrogen excretion from cattle, J. Dairy Sci. 98(5), 3025-3035.

Reynolds, C. K. (2006). Splanchnic metabolism of amino acids. In: Sejrsen, K., Hvelplund, T. and Nielsen, M. O. (Eds) Ruminant Physiology. Digestion, Metabolism and Impact of Nutrition on Gene Expression, Immunology and Stress'. The Netherlands: Wageningen Academic Publishers, pp. 225-248.

Reynolds, C. K., Crompton, L. A. and Mills, J. A. N. (2011). Improving the efficiency of energy utilisation in cattle, Anim. Prod. Sci. 51(1), 6-12.

Reynolds, C. K., Crompton, L. A., Mills, J. A. N., Humphries, D. J., Kirton, P., Relling, A. E., Misselbrook, T. H., Chadwick, D. R. and Givens, D. I. (2010). Effects of diet protein level and forage source on energy and nitrogen balance and methane and nitrogen excretion in lactating dairy cows. In: Corvetto, G. M. (Ed) Proceedings of the 3rd International Symposium on Energy and Protein Metabolism. EAAP Publ. No. 127. Wageningen, the Netherlands: Wageningen Academic Publishers.

Reynolds, C. K., Humphries, D. J., Kirton, P., Kindermann, M., Duval, S. and Steinberg, W. (2014). Effects of 3-nitrooxypropanol on methane emission, digestion, and energy and nitrogen balance of lactating dairy cows, J. Dairy Sci. 97(6), 3777-3789.

Rotz, C. A. (2018). Modeling greenhouse gas emissions from dairy farms', J. Dairy Sci. 101(7), 6675-6690.

Ruppert, L. D., Drackley, J. K., Bremmer, D. R. and Clark, J. H. (2003). Effects of tallow in diets based on corn silage or alfalfa silage on digestion and nutrient use by lactating dairy cows, J. Dairy Sci. 86(2), 593-609.

Russell, J. B. and Hespell, R. B. (1981). Microbial rumen fermentation, J. Dairy Sci. 64(6), 1153-1169.

Svihus, B., Uhlen, A. K. and Harstad, O. M. (2005). Effect of starch granule structure, associated components and processing on nutritive value of cereal starch: a review, Anim. Feed Sci. Technol. 122(3-4), 303-320.

Tapio, I., Snelling, T. J., Strozzi, F. and Wallace, R. J. (2017). The ruminal microbiome associated with methane emissions from ruminant livestock, J. Anim. Sci. Biotechnol. $8,7$.

Tempelman, R. J., Spurlock, D. M., Coffey, M., Veerkamp, R. F., Armentano, L. E., Weigel, K. A., de Haas, Y., Staples, C. R., Connor, E. E., Lu, Y. Y. and VandeHaar, M. J. (2015). Heterogeneity in genetic and nongenetic variation and energy sink relationships 
for residual feed intake across research stations and countries, J. Dairy Sci. 98(3), 2013-2026.

Thoma, G., Popp, J., Nutter, D., Shonnard, D., Ulrich, R., Matlock, M., Kim, D. S., Neiderman, Z., Kemper, N., East, C. and Adom, F. (2013). Greenhouse gas emissions from milk production and consumption in the United States: a cradle-to-grave life cycle assessment circa 2008, Int. Dairy J. 31, S3-S14.

Tyrrell, H. F., Moe, P. W. and Flatt, W. P. (1970). Influence of excess protein intake on energy metabolism of the dairy cow. In: Schurch, A. and Wenks, C. (Eds) Energy Metabolism of Farm Animals,. EAAP Publ. No. 13. Zurich: Juris Verlag pp.69-72.

USEPA. (2021). Inventory of U. S. Greenhouse Gas Emissions and Sinks: 1990-2019. Washington, DC: United States Environmental Protection Agency.

Uwizeye, A., de Boer, I. J. M., Opio, C. I., Schulte, R. P. O., Falcucci, A., Tempio, G., Teillard, F., Casu, F., Rulli, M., Galloway, J. O., Leip, A., Erisman, J. W., Robinson, T. P., Stenfeld, H. and Gerber, P. J. (2020). Nitrogen emissions along global livestock supply chains, Nat. Food 1(7), 437-446, https://doi.org/10.1038/s43016-020-0113-y.

Van Nevel, C. J. and Demeyer, D. I. (1996). Control of rumen methanogenesis, Environ. Monit. Assess. 42(1-2), 73-97.

Van Soest, P. J. (1994). Nutritional Ecology of the Ruminant (2nd edn.). Ithaca, NY: Cornell University Press.

VandeHaar, M. J. (1998). Efficiency of nutrient use and relationship to profitability on dairy farms, J. Dairy Sci. 81(1), 272-282.

VandeHaar, M. J., Armentano, L. E., Weigel, K., Spurlock, D. M., Tempelman, R. J. and Veerkamp, R. (2016). Harnessing the genetics of the modern dairy cow to continue improvements in feed efficiency, J. Dairy Sci. 99(6), 4941-4954.

VandeHaar, M. J. and St-Pierre, N. (2006). Major advances in nutrition: relevance to the sustainability of the dairy industry, J. Dairy Sci. 89(4), 1280-1291.

Waghorn, G. C., Macdonald, K. A., Williams, Y., Davis, S. R. and Spelman, R. J. (2012). Measuring residual feed intake in dairy heifers fed an alfalfa (Medicago sativa) cube diet, J. Dairy Sci. 95(3), 1462-1471.

Wallace, R. J., Snelling, T. J., McCartney, C. A., Tapio, I. and Strozzi, F. (2017). Application of metaomics techniques to understand greenhouse gas emissions originating from ruminal metabolism, Genet. Sel. Evol. 49(1), 9.

Wilkerson, V. A., Glenn, B. P. and McLeod, K. R. (1997). Energy and nitrogen balance in lactating cows fed diets containing dry or high moisture corn in either rolled or ground form, J. Dairy Sci. 80(10), 2487-2496.

Wilkinson, J. M. and Garnsworthy, P. C. (2017). Dietary options to reduce the environmental impact of milk production, J. Agric. Sci. 155(2), 334-347.

Williams, Y. J., Pryce, J. E., Grainger, C., Wales, W. J., Linden, N., Porker, M. and Hayes, B. J. (2011). Variation in residual feed intake in Holstein-Friesian dairy heifers in southern Australia, J. Dairy Sci. 94(9), 4715-4725.

Yang, W. Z., Beauchemin, K. A. and Rode, L. M. (2001). Effects of grain processing, forage to concentrate ratio, and forage particle size on rumen $\mathrm{pH}$ and digestion by dairy cows, J. Dairy Sci. 84(10), 2203-2216. 
